\title{
Post-fire resprouting ability of 15 non-dominant shrub and tree species in Mediterranean areas of NE Spain
}

\author{
Lidia QuEVEDo, Anselm RodRIGo*, Josep Maria EsPELTA \\ Unit of Ecology and Center for Ecological Research and Forestry Applications (CREAF), Autonomous University of Barcelona, \\ 08193 Bellaterra (Barcelona), Spain
}

(Received 19 February 2007; accepted 27 April 2007)

\begin{abstract}
Post-fire resprouting ability of the non-dominant tree and shrub species of the Mediterranean Basin has not yet been experimentally tested, although this group contributes to maintain the richness of Mediterranean plant communities. In this study, we have analyzed the post-fire recovery ability of 15 woody species that occur in relatively low abundance in dry and sub humid Mediterranean areas in NE of Spain. The main goals have been: (i) to determine experimentally the post-fire resprouting ability of these species and (ii) to compare the abundance of these species in areas affected by wildland fires and in unburned areas. We have observed a high resprouting ability after prescribed burning of most species except for Juniperus communis and $J$. phoenicea which showed a null resprouting. As the species with high resprouting ability showed similar presence in burned and unburned areas, we can conclude that wildfires are not a factor that constrains the presence of these species in Mediterranean woodlands. However, we found a reduction in the abundance of J. communis and J. phoenicea at the regional level after wildland fires.
\end{abstract}

distribution area / prescribed burning / resprouting / woody species / Juniperus

Résumé - Capacité à rejeter de souche de 15 espèces d'arbres et d'arbustes secondaires de la région méditerranéenne après incendie. La capacité à rejeter de souche après incendie d'espèces d'arbres et d'arbustes non dominants de la région méditerranéenne est peu connue malgré l'importance de la contribution de ce groupe à la richesse des communautés végétales. Dans cette étude, nous avons analysé la capacité à rejeter de souche de 15 espèces ligneuses présentes en faible abondance dans les zones semi arides et subhumides méditerranéennes du nord-est de l'Espagne. Les principaux objectifs étaient : (i) de déterminer expérimentalement la capacité de rejeter après incendie et (ii) de comparer l'abondance de ces espèces dans des zones brûlées et non brûlées. Toutes les espèces testées présentaient une grande capacité à rejeter de souche à l'exception de Juniperus communis et J. phoenicea, qui ont montré une incapacité complète à rejeter de souche après incendie. Les espèces présentant une grande capacité de rejet présentent des abondances similaires dans des zones brûlées et non brûlées. Nous pouvons conclure que les incendies ne sont pas le facteur limitant leur présence dans les forêts méditerranéennes. Au contraire, les espèces sensibles à faible capacité de rejet comme J. communis et J. phoenicea, ont vu leur abondance baisser à l'échelle régionale après incendie.

distribution des espèces / incendies de forêt / rejet de souche / brûlis / Juniperus

\section{INTRODUCTION}

Wildfires are considered the most important disturbance in Mediterranean-type ecosystems [38]. During recent decades, the number and, especially, the surface burned by forest fires in the Mediterranean Basin has increased dramatically with some catastrophic wildland fires being responsible for most of the burned areas [39]. Moreover, in recent years, a greater incidence of fire in non-fire-prone sub-Mediterranean areas along the east coast of the Iberian Peninsula has been detected (i.e., in Catalonia the percentage of surface burned in these areas increased from $23-26 \%$ in the seventies and eighties to $36 \%$ in the nineties). Thus, fires are gradually disturbing greater land surfaces and starting to threaten plant communities distributed in areas with a sub-humid Mediterranean climate, which traditionally have been less influenced by this type of disturbance.

Many Mediterranean plant species exhibit the ability to recover readily after fire, either through the germination of pro-

* Corresponding author: Anselm.Rodrigo@uab.es tected seeds stored in the soil seed bank or in the canopy [24], or by resprouting from aerial or subterranean fire-resistant buds $[17,21,26,38]$. The resprouting ability of some of the most dominant tree and shrub species in the Mediterranean Basin is well known (e.g. [1, 6, 20, 23, 28]). The extensive knowledge about the post-fire behaviour of these dominant forest species contrasts with the lack of information about the recovery of other non-dominant and less abundant tree and shrub species. Many of these less abundant species are of great importance in Mediterranean-type forest communities because: (i) they contribute to maintain the richness of Mediterranean forest communities [24] which, in general, tend to be dominated by one or two tree species $[25,37]$ and (ii) they play an important role as a source of pollen for insects, as well as fleshy fruits consumed by insects, mammals and birds $[8,13,18]$.

As far as we know, the post-fire resprouting ability of most of these non-dominant tree and shrub species present in the Mediterranean Basin has not yet been experimentally 
tested. However, for some of them, this potential ability has been partly envisaged after other disturbances such as thinning $[5,19]$. The potential resprouting ability after fire can be vital to the persistence of these species, because the latter do not potentially form a seed bank resistant to fire in the soil or in the canopy [23]. Therefore, depending on their resprouting ability after fire, some of these species could either disappear or even achieve greater dominance in the community, especially in those cases where the post-fire regeneration of the dominant species is very limited $[31,33]$.

In this study, we have analysed the post-fire resprouting ability of 15 forest tree and shrub species broadly distributed throughout humid and dry Mediterranean areas of the NE Iberian Peninsula, but present in low abundance, although most of them are abundant and representative of the Eurosiberian region. For this study we selected species of the genus Acer, Ilex, Sorbus, Amelanchier, Cornus, Crataegus, Juniperus, Prunus and Viburnum. The main goals of this study have been to determine for each of the studied species: (1) whether or not they have post-fire resprouting ability, (2) if there is a relationship between resprouting vigour and pre-fire size of the individuals and (3) whether the abundance of these species in their natural distribution areas is related to their ability to recover after fire. The first two goals of this study have been tested using a prescribed burning experiment. The third goal has been addressed in areas affected by wildland fires through a comparison of the presence/absence of these species in burned and unburned neighbouring areas.

\section{MATERIAL AND METHODS}

\subsection{Study species}

For this study, a total of 15 tree and shrub species distributed throughout the region of Catalonia (NE Iberian Peninsula) were chosen. We included deciduous species: Acer campestre L., A. monspessulanum L., A. opalus Mill., Sorbus domestica L., S. torminalis (L.) Crantz, Amelanchier ovalis L., Cornus sanguinea L., Crataegus monogyna L., Prunus spinosa L. and Viburnum lantana L.; evergreen broad-leafed: Ilex aquifolium L. and Viburnum tinus L.; and evergreen needle-leafed: Juniperus communis L., J. oxycedrus L. and J. phoenicea L., In sub-humid and dry Mediterranean areas of NE Spain, the abundance of these species is relatively low and they are either situated in the understory or they form small clumps in woods dominated mainly by Pinus or Quercus species.

\subsection{Post-fire resprouting ability}

The study has been conducted at seven sites with a Mediterraneantype climate located in Catalonia, NE Iberian Peninsula. In the areas included in the study, mean annual precipitation ranged from 595 to $853 \mathrm{~mm}$, mean annual water deficit (annual potential evapotranspiration - annual precipitation) ranged from -17 to $404 \mathrm{~mm}$ and mean annual temperatures between 10.4 and $13.2^{\circ} \mathrm{C}$. All the sites had an overstory dominated by Pinus spp. In all study sites, from March 2003 until May 2004, about 30 individuals of each species were sampled, with the exception of A. monspessulanum, for which just 15 were found. The whole set of individuals were tagged with metallic tags and positioned with a GPS. For each individual the crown cover (measuring two perpendicular diameters of the crown and computing the projection as an ellipse) and total number of stems was determined. In each stem we measured total height, distance from ground to beginning of the crown and basal diameter (see Annex 1). With these data the following calculations were carried out for each individual: height of highest stem, mean height of the stems; mean and minimum distance from the ground to the top of the crown; total basal area (adding together the basal area of all stems); and equivalent diameter of each individual obtained from the total basal area at ground level.

During winter and spring of 2003 and 2004, prescribed burnings were carried out in all study sites (temperatures during the burns ranging from $6.9^{\circ} \mathrm{C}$ to $18.2^{\circ} \mathrm{C}$ and with relative humidity never less than $47 \%$ ). The area burned varied from 0.43 to 4.5 ha. Immediately after fire, for each sampled individual we estimated an index of fire impact, calculated as the percentage of total individual height achieved directly by the fire flames (identified by the presence of leaves consumed or charred bark). Between June and October of 2004 (one or two years after the burning, depending on the site), all tagged individuals were located and we recorded whether they had resprouted or not. Moreover, the number of resprouts for each individual, the height of the three largest ones and the crown cover of the whole set of resprouts was measured. In none of the resprouted individuals was any effect of vertebrate herbivory detected.

In order to establish a relationship between resprouting vigour and the pre-fire size, the relationship between different structural variables measured before and after prescribed burning was analysed. To avoid spurious relationships, we previously constructed a correlation table among all pre-fire variables $(X)$. When there appeared to be correlation between two variables, one of them was chosen as the representative. After this procedure, all pairs of variables had a correlation coefficient lower than 0.8 . Following this criterion, the variables selected as independent and representative of the pre-fire size were: the number of stems, the maximum stem height and the basal area of each individual. The same was done for the post-fire variables $(Y)$ and the dependent variables selected as representative of the post-fire resprouting vigour were: basal area, the number of resprouts and the height of the dominant resprout. Finally, with the selected variables, we calculated step by step regression for each species between the pre- and the post-fire size variables.

Prescribed burning was carried out over two consecutive years (2003 and 2004). Thus, when taking post-fire measurements, individuals with 1 or 2 years of regeneration could be found. In order to analyse the relationship between the resprouting vigour and the prefire individual size, in those species where the great majority of individuals were in one of the two regeneration ages, only the individuals of the most numerous group were selected for the regressions. Only in the case of A. ovalis, which did not belong to a majority group, were all the individuals included in the study and the data from both regeneration ages was analysed separately.

In order to assess which species had the greatest growth ability after fire, the annual growth of all resprouts was compared. For the one-year-old resprouts, the measurement of the highest resprout in the field was used. In the case of two-year-old resprouts, the dominant resprout height was divided by two in order to obtain comparable data. Height differences among species were tested using two separate oneway ANOVA, one for the shrub species and another for tree species. When there were significant differences between species, we carried 
Table I. Resprouting ability after prescribed burning, measured as the percentage of individuals resprouting after fire, and degree of fire impact, measured as the percentage (mean \pm S.D.) of the individual achieved directly by the fire (see Methods). The number of localities where the species is present is shown in the last column. Species have been grouped according to their very high, high or non-resprouting ability after prescribed burning.

\begin{tabular}{|c|c|c|c|c|c|}
\hline Species & $\begin{array}{l}\text { Resprouted } \\
\text { individuals }\end{array}$ & $\begin{array}{l}\text { Non resprouted } \\
\text { individuals }\end{array}$ & $\begin{array}{l}\text { Resprouting } \\
\text { ability (\%) }\end{array}$ & $\begin{array}{l}\text { Fire impact } \\
\text { degree }(\%)\end{array}$ & $\begin{array}{l}\text { Number } \\
\text { of localities }\end{array}$ \\
\hline \multicolumn{6}{|c|}{ Very high resprouting ability after prescribed burning } \\
\hline A. opalus & 30 & 0 & 100 & $100 \pm 0$ & 1 \\
\hline A. ovalis & 34 & 0 & 100 & $100 \pm 0$ & 6 \\
\hline S. domestica & 33 & 0 & 100 & $93 \pm 24$ & 3 \\
\hline S. torminalis & 36 & 0 & 100 & $100 \pm 0$ & 1 \\
\hline V. lantana & 31 & 0 & 100 & $94 \pm 21$ & 3 \\
\hline V. tinus & 33 & 0 & 100 & $93 \pm 24$ & 1 \\
\hline C. sanguinea & 29 & 1 & 97 & $100 \pm 0$ & 3 \\
\hline A. campestre & 34 & 2 & 94 & $93 \pm 22$ & 4 \\
\hline C. monogyna & 32 & 2 & 94 & $100 \pm 0$ & 3 \\
\hline P. spinosa & 28 & 2 & 93 & $100 \pm 0$ & 4 \\
\hline A. monspessulanum & 14 & 1 & 93 & $100 \pm 0$ & 4 \\
\hline \multicolumn{6}{|c|}{ High resprouting ability after prescribed burning } \\
\hline J. oxycedrus & 26 & 6 & 81 & $40 \pm 38$ & 4 \\
\hline I. aquifolium & 29 & 10 & 74 & $99 \pm 32$ & 1 \\
\hline \multicolumn{6}{|c|}{ Non resprouting ability after prescribed burning } \\
\hline J. communis & 0 & 37 & 0 & $65 \pm 32$ & 3 \\
\hline J. phoenicea & 0 & 33 & 0 & $43 \pm 31$ & 2 \\
\hline
\end{tabular}

out post-hoc comparison using the Tukey test. In all statistical analyses, residuals were systematically inspected in order to check for normality and homoscedasticity, and data were log or arcsine square root transformed when necessary

\subsection{Presence of the studied species in the burned and unburned areas}

The comparison of the presence of the studied species in burned areas by wildland fires versus unburned areas was done by overlaying different maps obtained with the SIG MiraMon package [30]. The first step was to identify and define the areas burned between 1975 and 2002 of more than 30 ha, from a selection of fire maps [34]. Most of them occurred in summer and were intense canopy fires. Secondly, around each burned zone an area of $3000 \mathrm{~m}$ from the limit was defined with the aim of creating a neighbouring unburned zone, comparable with the zone which had been burned. Then we overlapped the actual distribution area for each species with the fire map and the neighbouring unburned zones. In the resulting map we counted, for each species, the number of plots of the Third National Forest Inventory of Spain (IFN3) within the species area distribution and in the burned areas where the species was present. Then, for each species, the same total number of plots in burned areas was randomly selected from the set of plots of the unburned areas and we counted the number of plots where the species was present. Finally, using an $\chi^{2}$ test, we tested differences in the number of plots where the species was present in burned and unburned areas.

\section{RESULTS}

The 15 species studied showed three differentiated types of responses, according to their resprouting ability after prescribed burning (Tab. I). Eleven species exhibit a very high resprouting ability, with more than $90 \%$ of the individuals resprouted (Tab. I). A second group of two species (I. aquifolium and $J$. phoenicea) present a considerable percentage of resprouting individuals (74-81\%), although lower than the former group. In both groups all the individuals resprouted from the root crown. Finally, two species (J. phoenicea and J. communis) had no resprouting ability at all. After the prescribed burning, $73 \%$ of all trees and shrubs studied appeared to be completely charred, while the aerial part of the remaining individuals also died (suffocated) as a consequence of the extremely high temperatures reached (Tab. I). For those two species resprouting with intermediate values, no differences in the degree of charring was observed between resprouting individuals and non-resprouting ones, neither for I. aquifolium $(t=1.09, p=0.26$ and d.f. $=35)$ nor for $J$. oxycedrus $(t=0.59, p=0.59$ and d.f. $=6)$.

For all species, resprouting vigour (Tab. II) was related to the pre-fire size of the individual (see Annex 1 and 2 for the mean values of the morphological variables before and after prescribed burning). However, this relationship differed among species, depending on the variables used to estimate resprouting vigour: either the number of new resprouts or the height of the dominant resprout. Pre-fire basal area was the 
Table II. $P$-values and correlation coefficients $\left(R^{2}\right)$ of the stepwise regression between pre-fire characteristics of individuals (total basal area (TBA), height of highest stem (Max. height) and number of stems) and the number of resprouts after fire (A) and the height of the dominant resprout after fire $(\mathbf{B})$. Significant terms included in the regression model are shown as positive $(+)$, negative $(-)$ or ns $=$ non significant terms. Number of individuals $(N)$ and regeneration age ( 1 or 2 y) are also shown.

\begin{tabular}{|c|c|c|c|c|c|c|c|}
\hline Species & $N$ & TBA & Max height & Number of stems & $p$-value & $R^{2}$ & Regeneration age (yrs) \\
\hline \multicolumn{8}{|c|}{ A. Number of resprouts after fire } \\
\hline A. campestre & 32 & + & ns & + & $<0.0001$ & 0.655 & 1 \\
\hline A. monspessulanum & 12 & ns & ns & ns & - & - & 2 \\
\hline A. opalus & 30 & + & ns & ns & 0.0112 & 0.209 & 1 \\
\hline \multirow[t]{2}{*}{ A. ovalis } & 21 & + & ns & ns & $<0.0001$ & 0.615 & 2 \\
\hline & 12 & ns & + & + & $<0.0001$ & 0.872 & 1 \\
\hline C. sanguinea & 28 & + & ns & ns & 0.0378 & 0.156 & 2 \\
\hline C. monogyna & 23 & + & ns & ns & 0.0066 & 0.302 & 1 \\
\hline I. aquifolium & 29 & + & ns & ns & 0.0067 & 0.242 & 1 \\
\hline J. oxycedrus & 20 & ns & + & ns & 0.0261 & 0.246 & 1 \\
\hline P. spinosa & 24 & $\mathrm{~ns}$ & ns & ns & - & - & 1 \\
\hline S. domestica & 31 & ns & ns & ns & - & - & 1 \\
\hline S. torminalis & 36 & + & ns & + & $<0.0001$ & 0.590 & 2 \\
\hline V. lantana & 29 & + & $\mathrm{ns}$ & ns & 0.0356 & 0.153 & 2 \\
\hline V. tinus & 30 & ns & ns & + & $<0.0001$ & 0.703 & 1 \\
\hline \multicolumn{8}{|c|}{ B. Height of the dominant resprout after fire } \\
\hline A. campestre & 32 & $\mathrm{~ns}$ & + & ns & $<0.0001$ & 0.545 & 1 \\
\hline A. monspessulanum & 12 & ns & + & ns & 0.0072 & 0.530 & 2 \\
\hline A. opalus & 30 & + & ns & ns & $<0.0001$ & 0.633 & 1 \\
\hline \multirow[t]{2}{*}{ A. ovalis } & 21 & + & ns & ns & $<0.0001$ & 0.604 & 2 \\
\hline & 12 & ns & ns & ns & - & - & 1 \\
\hline C. sanguinea & 28 & ns & + & ns & 0.0144 & 0.209 & 2 \\
\hline C. monogyna & 23 & + & ns & ns & 0.0423 & 0.182 & 1 \\
\hline I. aquifolium & 29 & $\mathrm{~ns}$ & ns & ns & - & - & 1 \\
\hline J. oxycedrus & 20 & ns & ns & ns & - & - & 1 \\
\hline P. spinosa & 24 & $\mathrm{~ns}$ & + & ns & 0.0046 & 0.312 & 1 \\
\hline S. domestica & 31 & ns & + & ns & 0.0008 & 0.327 & 1 \\
\hline S. torminalis & 36 & + & ns & ns & $<0.0001$ & 0.801 & 2 \\
\hline V. lantana & 29 & $\mathrm{~ns}$ & + & + & $<0.0001$ & 0.738 & 2 \\
\hline V. tinus & 30 & + & + & ns & $<0.0001$ & 0.769 & 2 \\
\hline
\end{tabular}

best predictor of the number of new resprouts occurring in 8 out of 13 species, followed by pre-fire number of stems (4 out of 13 species) and finally, maximum height (Tab. IIA). Only for A. monspessulanum, and P. spinosa was the number of new resprouts independent of the size of the individuals before the fire. On the other hand, for the height of the dominant resprout, in 6 out of 13 species there was a positive relationship with the pre-fire height of the individuals (Tab. IIB), the second variable being the basimetric area (5 out of 13 species) and, finally, the number of stems (only one species). None of the parameters analysed exerted an effect on the dominant resprout height of A. ovalis, I. aquifolium and J. oxycedrus.

Figure 1 shows the annual growth of all the species able to resprout after prescribed burning. Significant differences in growth were detected between both tree species (ANOVA
$F=19.7, p<0.0001$ and d.f. $=5$ ) and shrubs (ANOVA, $F=30.1, p<0.0001$ and d.f. $=6$ ). Among the tree species, $A$. campestre and, to a lesser extent, $S$. domestica, were those with the highest post-fire growth. I. aquifolium presented lower growth than other species, while height of new resprouts was only $9 \%$ of its pre-fire height. Regarding shrub species, $P$. spinosa and $C$. monogyna had the highest growth, the other species barely surpassing $20 \mathrm{~cm}$ in height.

A comparison of the presence of the studied species in areas burned by wildland fires and unburned neighbouring areas is presented in Table III. Four of the species analysed did not show any significant difference in their presence between burned and unburned zones. However, A. ovalis and $J$. phoenicea showed a significant reduction in their presence in burned versus unburned zones, while the presence of 
J. communis was not detected in burned plots, although the presence of this species was also relatively low in neighbouring unburned zones.

\section{DISCUSSION}

Most of the 15 species analysed had high resprouting ability after prescribed burning; with the exception of J. соттиnis and J. phoenicea, which had no resprouting ability at all. Moreover, for the 13 species that resprouted, the percentage of resprouting was very high, attaining values higher than $90 \%$ in most cases and even 100\% in 6 species. These values are similar to those experimentally registered for dominant forest tree and shrub species in Mediterranean-type ecosystems with well-known resprouting ability after fire $[4,20,22,28,32]$. Interestingly, resprouting ability was not conditioned by the fire impact degree experienced (e.g., Acer sp. individuals were completely burned but all of them resprouted, while J. communis and J. phoenicea individuals were less severely burned but only $65-43 \%$ of them resprouted, see Tab. I).

In V. tinus and J. oxycedrus, the resprouting values obtained in this study were higher than those registered by López Soria and Castell (1992) (100 and 83\%. in our study vs. 83 and 55\%, respectively). Our higher values could be related to the fact that the study sites were affected by prescribed burnings instead of wildland fires. Vegetation response to fire can vary widely, depending on the burning season $[3,36]$. In particular, in Mediterranean ecosystems, resprouting ability after summer wildland fires could be lower than after prescribed burning because: (i) prescribed burning generally reaches lower intensities than wildland fires $[2,3,16]$ and (ii) summer water stress can reduce resprouting vigour [1]. However, it is worth mentioning that for those species which in this study have shown intermediate resprouting values, such as I. aquifolium and $J$. oxycedrus, those individuals which did not resprout did not suffer greater burning intensities than those which had resprouted. In this context, the influence of other environmental variables in the resprouting process, such as topographic position [15] and resource availability [7], should be considered as a possible explanation of the above-mentioned differences.

As shown in Tables IIA and IIB, resprouting vigour was related with the pre-fire size of the individual [22]. Although there were some species-specific differences, in general, individuals that were bigger in terms of basimetric area or their greater number of stems produced more resprouts after disturbance $[9-11,32]$. This pattern has been explained by the presence of a greater number of potential buds forming resprouts (bud bank) in larger individuals $[4,35,40]$. Conversely, the analysis of the effect of pre-fire height of the individual on the height of the dominant new resprouts has been more heterogeneous, with a major influence of basal area in some species and pre-fire height in others (Tab. IIB). The lack of a clear relationship between the height of new resprouts after a disturbance and pre-fire size has been observed in other studies, and has been explained by the effect that some environmental factors (i.e., shadow) could have on the height of resprouts or a major dependence of this variable on resource
A)

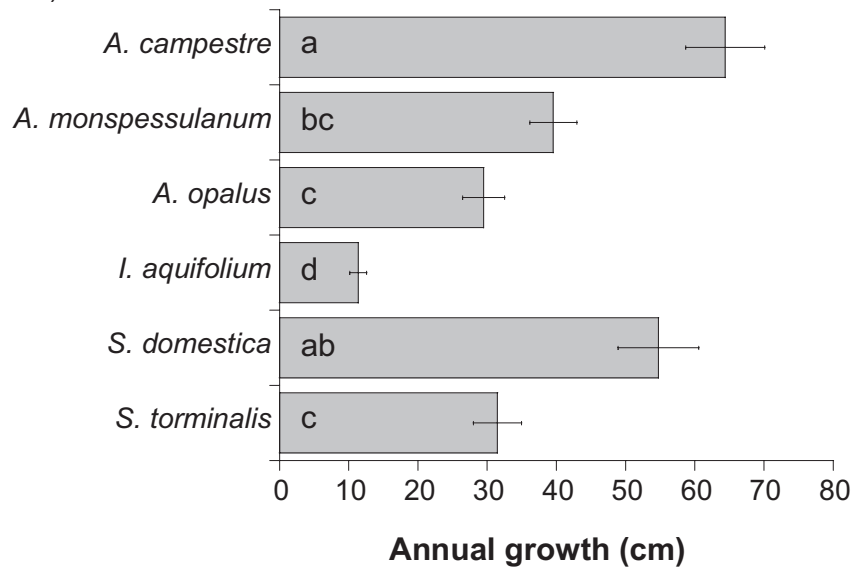

B)

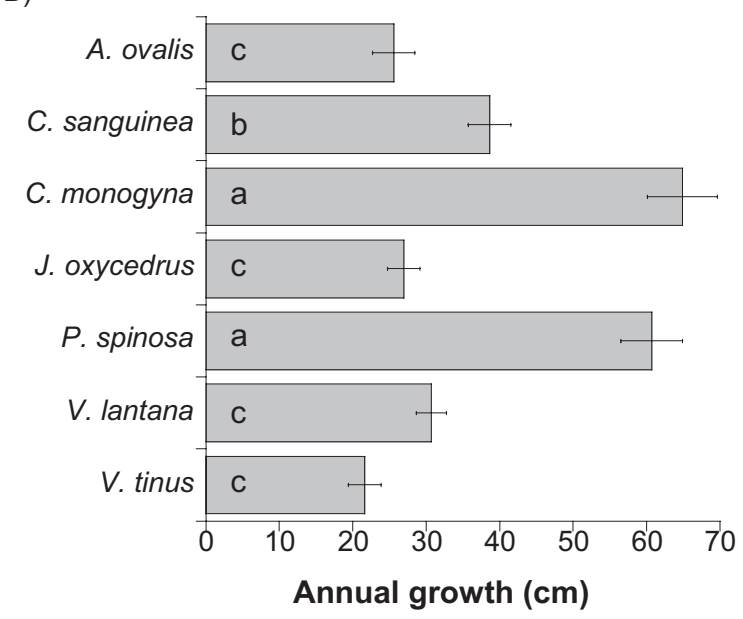

Figure 1. Mean $\pm \mathrm{SE}$ annual growth after prescribed burning of the dominant resprouts of tree (A) and shrub (B) species. Significant differences among species according to the Tukey test are shown with different letters.

availability and site quality $[7,10,15]$. Despite the abovementioned differences between species, it is important to stress that in none of the species were the number and height of new resprouts totally independent of pre-fire size of the individuals. This fact, coupled with the high resprouting ability shown by most species, suggests that fire does not cause a significant change in the size structure of the population.

Due to historical management practice, most of the studied species are usually found suppressed in the understory of Pinus sp. and Quercus sp. forests, under shadow conditions and low growth. According to our results, for some species, a high annual growth of the dominant resprouts was found (Fig. 1 and Annex 2). Thus, after the elimination of the dominant trees of the community by fire, this rapid recovery suggests that post-fire conditions could allow some of these species to become dominant in their forest formations. This could occur especially with $A$. campestre and $S$. domestica (with the highest growth) but also with A. monspessulanum, A. opalus and S. torminalis (Fig. 1). This pattern would be especially 
Table III. Percentage of the IFN3 forestry inventory plots included in the distribution area of each species where the species is present within burned areas (wildland fires between 1975 and 2002) and within neighbouring unburned areas (see Methods for details). When a $\chi^{2}$ test could be used for comparison p-value is shown. A significantly lower presence of the species in burned areas is indicated as $(\downarrow)$ and non-significant differences as $(=) . N$ is the total number of burned or unburned plots used in the comparison. Categories of resprouting ability are defined in Table I.

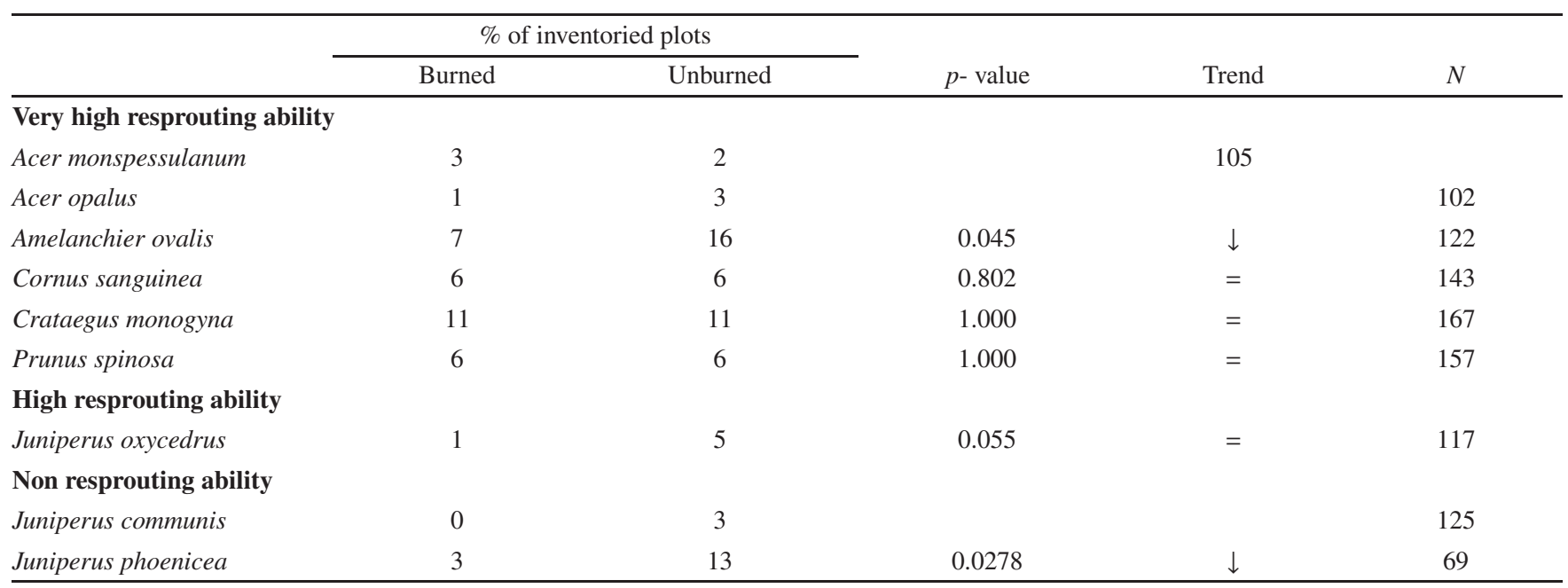

important in those burned areas occupied by pine tree species without resprouting ability and a low seedling establishment after fire [31,33].

The presence of the species included in this study in forest inventories is usually low, it being difficult to establish their regional distribution from forest databases. As a consequence, differences in presence in burned vs. unburned areas could only be statistically evaluated for 6 of the species studied. Despite these difficulties, it was possible to establish that all species with similar presence in burned and unburned areas have also exhibited a high resprouting level. A. ovalis is an exception because, despite its very high resprouting ability (Tab. I), its presence seems to diminish in burned areas (Tab. III). On the other hand, it should be mentioned that none of the species have shown a significant increase of their presence in burned areas. This fact suggests that these species are able to maintain their pre-fire populations through resprouting, but they have a low establishment ability of new individuals in burned areas.

Despite the relatively favourable conditions when prescribed burning was conducted (winter and spring), two species (J. phoenicea and J. communis) have shown a null resprouting ability, as suggested by previous studies after wildland fires [14,23,27]. Remarkably, both species are able to survive other types of disturbances (e.g., intensive grazing [12]). Due to this inability to resprout after fire and the fact that these species do not form seed banks resistant to fire, maintenance of populations in burned areas will depend on the arrival of propagules from unburned edges. The increase in recent years of large fire events in the Mediterranean Basin [29] constrains the arrival of propagules. Furthermore, J. communis recruitment only occurs in optimal precipitation conditions [14]. On the other hand, it is well known that J. phoenicea germination is slow and difficult and that seed production is irregular, and that it may take 50 years for plants to reach sexual maturity [27]. These constraints imply that only the inclusion of specific measures in restoration plans would prevent a reduction in the populations of these two species at regional level after fire events.

Acknowledgements: Thanks are due to M.J. Broncano, Javier Retana and Montserrat Vilà for their very helpful comments on an earlier draft of the manuscript and to GRAF (Grup de Recolzament d'Actuacions Forestals) for carrying out prescribed burning. This research was partly funded by INTERREG III (EU) project I3A-1-100-E and by INIA project RTA2005-00100-C02.

\section{REFERENCES}

[1] Bonfil C., Cortés P., Espelta J.M., Retana J., The role of disturbance in the coexistence of the evergreen Quercus ilex and the deciduous Quercus cerrioides, J. Veg. Sci. 15 (2004) 423-430.

[2] Bradstock R.A., Auld T.D., Soil temperatures during experimental bushfires in relation to fire intensity: consequences for legume germination and fire management in south-eastern, Aust. J. Appl. Ecol. 32 (1995) 76-84.

[3] Brockway D.G., Gatewood R.G., Paris R.B., Restoring fire as an ecological process in shortgrass prairie ecosystems: initial effects of prescribed burning during the dormant and growing seasons, J. Environ. Manage. 65 (2002) 135-152.

[4] Canadell J., Lloret F., López Soria L., Resprouting vigour of two Mediterranean shrub species after experimental treatment, Vegetatio 95 (1991) 119-126.

[5] Clennett C., Viburnum tinus 'Eve Price'. Viburnaceae, Royal Botanic Gardens, Kew, Blackwell Publishing Ltd, Oxford, 2004.

[6] Clemente A.S., Rego F.C., Correia O.A., Demographic patterns and productivity of post-fire regeneration in Portuguese Mediterranean maquis, Int. J. Wildl. Fire 6 (1996) 5-12.

[7] Cruz A., Perez B., Quintana J.R., Moreno J.M., Resprouting in the Mediterranean-type shrub Erica australis affected by soil resource availability, J. Veg. Sci. 13 (2002) 641-650. 
[8] Debussche M., Isenmann P., Bird-dispersed seed rain and seedling establishment in patchy Mediterranean vegetation, Oikos 69 (1994) 414-426.

[9] Ducrey M., Turrel M., Influence of cutting methods and dates on stump sprouting in holm oak (Quercus ilex L.) coppice, Ann. Sci. For. 49 (1992) 449-464.

[10] Espelta J.M., Retana J., Habrouk A., Resprouting patterns after fire and response to stool cleaning of two coexisting Mediterranean oaks with contrasting leaf habits on two different sites, For. Ecol. Manage. 179 (2003) 401-414.

[11] Espelta J.M., Retana J., Habrouk A., Response to natural and simulated browsing of two Mediterranean oaks with contrasting leaf habit after a wildlife, Ann. For. Sci. 63 (2006) 441-447.

[12] Fernández-Guillen M.D., Estudio comparativo de la vegetación leñosa de un área representativa de la Sierra de Guadarrama, Ph.D. thesis, Universidad complutense de Madrid, 1996, http://www.ucm.es/BUCM/tesis/19911996/X/3/X3002801.pdf.

[13] García D., Obeso J.R., Martinez I., Spatial concordance between seed rain and seedling establishment in bird-dispersed trees: does scale matter? J. Ecol. 93 (2005) 693-704.

[14] García D., Zamora R., Hódar J.A., Gómez J.M., Age structure of Juniperus communis L. in the Iberian peninsula: Conservation of remnant populations in Mediterranean mountains, Biol. Conserv. 87 (1999) 215-220.

[15] Gracia M., Retana J., Effect of site quality and shading on sprouting patterns of holm oak coppices, For. Ecol. Manage. 188 (2004) 39-49.

[16] De Las Heras J., Bonilla M., Martinez L.W., Early vegetation dynamics of Pinus tropicalis Morelet forests after experimental fire (W Cuba), Ann. For. Sci. 62 (2005) 771-777.

[17] Hodgkinson K.C., Sprouting success of shrubs after fire: heightdependent relationships for different strategies, Oecologia 115 (1998) 64-72.

[18] Hulme P.E., Post-dispersal seed predation and the establishment of vertebrate dispersed plants in Mediterranean shrublands, Oecologia 111 (1997) 91-98.

[19] Kollmann J., Grubbs P.J., Viburnum lantana L. and Viburnum opulus L. (V. lobatum Lam., Opulus vulgaris Borkh.), J. Ecol. 90 (2002) 1044-1070.

[20] López-Soria L., Castell C., Comparative genet survival after fire in woody Mediterranean species, Oecologia 53 (1992) 493-499.

[21] Lloret F., Fire, canopy cover and seedling dynamics in Mediterranean shrubland of northeastern Spain, J. Veg. Sci. 9 (1998) 417-430.

[22] Lloret F., López-Soria L., Resprouting of Erica multiflora after experimental fire treatments, J. Veg. Sci. 4 (1993) 367-374.

[23] Lloret F., Vilà M., Diversity patterns of plant functional types in relation to fire regime and previous land use in Mediterranean woodlands, J. Veg. Sci. 14 (2003) 387-398.

[24] Myers N., Mittermeier R.A., Mittermeier C.G., da Fonseca G.A.B., Kent J., Biodiversity hotspots for conservation priorities, Nature 403 (2000) 853-858.
[25] Naveh Z., Lieberman A.S., Dynamic conservation management of Mediterranean landscapes, in: Naveh Z., Lieberman A.S. (Eds.), A Landscape Ecology, theory and application, Springer-Verlag, New York, 1984, pp. 256-269.

[26] Noble I.R., Slatyer R.O., The use of vital attributes to predict successional changes in plant communities subject to recurrent disturbances, Vegetatio 43 (1980) 5-21.

[27] Papió C., Respuesta al fuego de las principales especies de la vegetación de Garraf (Barcelona), Orsis 3 (1988) 87-103.

[28] Pausas J.G., Resprouting of Quercus suber in NE Spain after fire, J. Veg. Sci. 8 (1997) 703-706.

[29] Pausas J.G., Changes in fire and climate in the eastern Iberian Peninsula (Mediterranean Basin), Clim. Change 63 (2004) 337350 .

[30] Pons X., MiraMon. Sistema d'Informació Geogràfica i software de Teledetecció, Centre de Recerca Ecològica i Aplicacions Forestals, Bellaterra, 2002.

[31] Retana J., Espelta J.M., Habrouk A., Ordóñez J.L., Solà-Morales F., Regeneration patterns of three Mediterranean pines and forest changes after a large wildfire in NE Spain, Ecoscience 9 (2002) 89-97.

[32] Riba M., Effects of intensity and frequency of crown damage on resprouting of Erica arborea L. (Ericaceae), Acta Oecol. 19 (1998) 9-16.

[33] Rodrigo A., Retana J., Picó X., Direct regeneration is not the only response of Mediterranean forests to large fires, Ecology 85 (2004) 716-729.

[34] Salvador R., Valeriano J., Pons X., Díaz-Delgado R., A semiautomatic methodology to detect fire scars in shrubs and evergreen forests with Landsat MSS time series, Int. J. Remote Sens. 4 (2000) $655-671$.

[35] Sennerby-Forsse L., Zsuffa L., Bud structure and resprouting in coppiced stools of Salix viminalis L., S. eriocephala Michx., and S. amygdaloides Anders, Trees 9 (1995) 224-234.

[36] Sparks J.C., Masters R.E., Engle D.M., Palmer M.W., Bukenhofer G.A., Effects of late growing-season and late dormant-season prescribed fire on herbaceous vegetation in restored pine-grassland communities, J. Veg. Sci. 9 (1998) 133-142.

[37] Terradas J., Holm oak and holm oak forests: an introduction, in: Rodà F., Retana J., Gracia C., Bellot J. (Eds.), Ecology of Mediterranean evergreen oak forests, Springer, Berlin, 1999, pp. 3-14.

[38] Trabaud L., Dynamics after fire of sclerophyllous plant communities in the Mediterranean basin, Ecol. Medit. 13 (1987) 25-37.

[39] Vázquez A., Moreno J.M., Patterns of lightning-, and people-caused fires in Peninsular Spain, Int. J. Wildl. Fire 8 (1998) 103-115.

[40] Vilà M., Terradas J., Sprout recruitment and self-thinning of Erica multiflora after clipping, Oecologia 102 (1995) 64-69. 
Annex 1. Main pre-fire structural characteristics (mean \pm S.E.) of the individuals of the different species. $N$ stems $=$ number of stems per individual, $\mathrm{Max} \mathrm{H}=$ height of the highest stem, $\mathrm{B}$ area $=$ basal area, $\mathrm{Cr}$ cov $=$ crown cover. $N=$ number of individuals sampled.

\begin{tabular}{|c|c|c|c|c|c|}
\hline Species & $N$ stems & Max H (cm) & $\mathrm{B}$ area $\left(\mathrm{cm}^{2}\right)$ & $\mathrm{Cr} \operatorname{cov}\left(\mathrm{m}^{2}\right)$ & $N$ \\
\hline A. campestre & $2.4 \pm 0.4$ & $197 \pm 21$ & $9.06 \pm 1.1$ & $5.4 \pm 0.9$ & 33 \\
\hline A. monspessulanum & $2.2 \pm 0.4$ & $187 \pm 30$ & $6.07 \pm 6.2$ & $7.1 \pm 3.3$ & 13 \\
\hline A. opalus & $1.4 \pm 0.1$ & $78 \pm 10$ & $1.57 \pm 2.3$ & $1.4 \pm 0.5$ & 30 \\
\hline A. ovalis & $8.7 \pm 2.1$ & $237 \pm 33$ & $3.99 \pm 8.49$ & $13.1 \pm 3.4$ & 13 \\
\hline A. ovalis & $3.2 \pm 0.5$ & $146 \pm 1$ & $2.51 \pm 3.70$ & $3.8 \pm 0.2$ & 21 \\
\hline C. sanguinea & $1.7 \pm 0.2$ & $117 \pm 14$ & $0.78 \pm 1.0$ & $1.8 \pm 0.5$ & 29 \\
\hline C. monogyna & $1.8 \pm 0.2$ & $133 \pm 15$ & $5.72 \pm 6.9$ & $4.8 \pm 1.2$ & 23 \\
\hline I. aquifolium & $3.3 \pm 0.5$ & $194 \pm 20$ & $22.6 \pm 42.3$ & $8.5 \pm 2.3$ & 39 \\
\hline J. communis & $1.5 \pm 0.4$ & $130 \pm 11$ & $14.4 \pm 16.3$ & $5.8 \pm 1.1$ & 19 \\
\hline J. communis & $1.1 \pm 0.1$ & $188 \pm 19$ & $12.6 \pm 11.1$ & $6.3 \pm 1.1$ & 18 \\
\hline J. oxycedrus & $2.1 \pm 0.4$ & $170 \pm 12$ & $41.4 \pm 56.4$ & $6.3 \pm 2.2$ & 25 \\
\hline J. phoenicea & $1.9 \pm 0.5$ & $210 \pm 18$ & $14.2 \pm 17.8$ & $5.0 \pm 0.9$ & 33 \\
\hline P. spinosa & $1.7 \pm 0.3$ & $79 \pm 6$ & $2.36 \pm 4.4$ & $0.8 \pm 0.2$ & 26 \\
\hline S. domestica & $1.5 \pm 0.1$ & $170 \pm 24$ & $2.74 \pm 3.5$ & $4.1 \pm 1.4$ & 31 \\
\hline S. torminalis & $1.7 \pm 0.2$ & $99 \pm 13$ & $1.19 \pm 1.82$ & $1.3 \pm 0.3$ & 36 \\
\hline V. lantana & $2.4 \pm 0.2$ & $114 \pm 10$ & $4.18 \pm 1.1$ & $2.2 \pm 0.4$ & 29 \\
\hline V. tinus & $4.2 \pm 0.7$ & $72 \pm 10$ & $1.82 \pm 4.9$ & $1.5 \pm 0.6$ & 30 \\
\hline
\end{tabular}

Annex 2. Main post-fire structural characteristics (mean \pm S.E.) of the individuals of the different species. $N$ resprouts $=$ number of new resprouts and $\mathrm{Max} \mathrm{H}=$ height of the dominant resprout. $N=$ number of individuals, Reg = number of years $(1$ or 2$)$ after prescribed burning when the individuals were sampled.

\begin{tabular}{|c|c|c|c|c|}
\hline Species & $\mathrm{N}$ resprouts & $\operatorname{Max} \mathrm{H}(\mathrm{cm})$ & $N$ & Reg (years) \\
\hline A. campestre & $12 \pm 2.3$ & $64 \pm 6$ & 32 & 1 \\
\hline A. monspessulanum & $13 \pm 3.9$ & $79 \pm 7$ & 12 & 2 \\
\hline A. opalus & $5 \pm 0.6$ & $29 \pm 3$ & 30 & 1 \\
\hline \multirow[t]{2}{*}{ A. ovalis } & $54 \pm 14$ & $41 \pm 9$ & 12 & 1 \\
\hline & $10 \pm 1.7$ & $57 \pm 7$ & 21 & 2 \\
\hline C. sanguinea & $5 \pm 0.5$ & $77 \pm 6$ & 28 & 2 \\
\hline C. monogyna & $9 \pm 1.1$ & $65 \pm 5$ & 23 & 1 \\
\hline I. aquifolium & $17 \pm 2.8$ & $11 \pm 1$ & 29 & 1 \\
\hline J. oxycedrus & $88 \pm 17$ & $27 \pm 2$ & 20 & 1 \\
\hline P. spinosa & $7 \pm 1.5$ & $61 \pm 4$ & 24 & 1 \\
\hline S. domestica & $3 \pm 0.7$ & $55 \pm 6$ & 31 & 1 \\
\hline S. torminalis & $4 \pm 0.6$ & $63 \pm 7$ & 36 & 2 \\
\hline$V$. lantana & $6 \pm 0.6$ & $61 \pm 4$ & 29 & 2 \\
\hline V. tinus & $7 \pm 1.1$ & $43 \pm 4$ & 30 & 2 \\
\hline
\end{tabular}

